\section{RE-DEDICATION OF SCIENCE IN GERMANY}

$\mathrm{T}$ HE first victin of Nazi anti-Semitism in Germany wereptets or persons of Jewish descent in official positid/s, for example at the universities ; with a small glass of exceptions, they were dismissed by a decrensued within six weeks of Hitler's final accession power. The great chemist Fritz Haber, direptor of the Kaiser Wilhelm Institut für Physikalis $h_{0}$ Chemie in Berlin-Dahlem, though by birth a Jew, did not himself fall under the decree, but a number of junior members of his staff did. Haber decided to resign in protest against this decree, and a few months later (in the summer of 1933) he left Germany. In his absence false accusations were levelled against him which rendered a return dangerous. He became an exile and died in exile on January 29, 1934 (see Nature, 133, 349 ; 1934).

Haber had been virtually the founder in 1912 of the Kaiser Wilhelm Institut für Physikalische Chemie, which he directed for twenty-one years. $\mathrm{He}$ also acted during this time as chief adviser to the president of the Kaiser Wilhelm Gesellschaft in the choice of candidates for senior appointments throughout the research institutes of the Society. Moreover, locally in Dahlem, the Institute under his direction was for a number of years the main centre of scientific discussions among the group of research institutes situated there. Haber's position was unsurpassed in Germany as an organiser of scientific life and thought.

Paying tribute to Haber's services, the Kaiser Wilhelm Gesellschaft and Haber's friends and pupils had planted in 1928 on Haber's sixtieth birthday a lime tree in front of the main entrance of his Institute, which was named the 'Haber Linde'. On the encircling stone parapet an inscription was engraved dedicating the tree to Fritz Haber. When a Nazi director took over the Institute, however, this visible tribute to Haber's activities was not allowed to survive. Though the lime tre $\theta$ was left standing, the inscription marking its origin was carefully chiselled away.

On Germany's defeat, Dahlem was incorporated in the American Sector of Berlin. Soon after the arrival there of the American occupational forces, news came through that the Haber Institute was still standing, but entirely empty. The Nazi occupants had been eliminated, but all equipment had vanished too. A little later it became known that the physicist Prof. Hartmut Kallmann, a former pupil and close collaborator of Haber for many years, had taken possession of the empty shell. Kallmann, who had himself narrowly escaped racial liquidation by the Nazis, had returned after eleven years of interruption of his scientific work, with the intention of re-starting once more, if possible, the great centre of physical chemistry in Dahlem.

Haber's memory was restored to honour. On February 2 of this year the 'Haber Linde' was solemnly re-dedicated and its inscription renewed. The chief speaker on the occasion was Prof. Kallmann; other addresses included those by the Ober-Burgermeister of Berlin, the Burgermeister of Dahlem and the director of the People's University of Berlin. Of Haber's closer colleagues there were present Prof. K. F. Bonhöffer and Prof. Otto Warburg.

In his speech Dr. Kallmann recalled that eleven years earlier Haber's memory had been honoured on the anniversary of his death by a gathering of his friends who had remained in Germany under the Nazis. Members of university staffs (who in Germany are State officials) were forbidden attendance by express order of the Government; yet the hall was packed-"all had come", said Kallmann. This certainly was a noteworthy manifestation of independence in German scientific circles.

Dr. Kallmann revealed that in 1935 he (with many others) had still thought of the Nazi regime as a passing phenomenon; the subsequent "unspeakable horrors beyond all human imagination" had not been expected. Outside observers may regard this error as throwing a serious responsibility on German academic circles. Of this Dr. Kallmann appears well aware. Urging the resumption of every effort to advance scientific knowledge and to cultivate the arts of peace, he adds that this "may perhaps be a modest contribution to the necessary reparation of the measureless disaster which has been brought upon the world from this country". "Perhaps," he continued, "this could also form a contribution to the reconciliation of peoples. Perhaps the people beyond the frontiers of this country would then cease to think only of its evils, but remember also that from this country work has been done which belongs to the noblest creations of the human mind."

In a letter recently received from Dr. Kallmann, I find the same burning enthusiasm for science which pervaded his speech. Work, work, honest work, he says, is the only possible way to the moral salvation of Germany ; and then-to my surprise-I find him expressing the confident hope to be soon granted a "licence for research" (Forschungserlaubnis). So apparently he has not yet been allowed to start research investigations.

It would seem to me that the values of science and humanity, restored to Germany by Allied victory, are damaged if people like Dr. Kallmann are still left to-day waiting for permission to resume their work. There may be, among those German men of science who resisted Nazism at great risk to themselves, some who occasionally lacked political acumen ; but we must respect their integrity and should not delay any longer upholding with them freely and openly the fellowship of science. M. PotANYI

\section{EXHIBITION OF BRITISH SCIENTIFIC INSTRUMENTS AT STOCKHOLM}

THE first exhibition of British manufactured goods to be held abroad since the War was held in Stockholm during/May 24-June 4. It was promoted by the British \&cientific Instrument Manufacturers' Association in co-operation with the Royal Swedish Academy of Zngineering Sciences, the Swedish Association of Tochnical Physicists and the British Council. The exhibjtion was housed in the Technical Museum, Stockholfo, by courtesy of the director, Mr. Althin.

Forty-one firms of scientific instrument manufacturers/participated, and a comprehensive display of recently developed apparatus was shown that should considerably enhance the prestipe of British-made goods in the Scandinavian countries. The fact that the invitation to arrange an exhibition emanated from Swedish sources is a measure of the interest of Swedish men of science and industrialists in British manufactured goods, and the demand that exists in that country for precision apparatus. 